\title{
Allergenicity Change of Soybean Proteins by Thermal Treatment Methods
}

\author{
Hui-Gyeong Seol', Yu-Jin Ko', Eun-Jung Kim¹, Gyeong-Lan Lee', Do-Gyeong Kim², Jeong-Ok Lee ${ }^{3,4}$, Kang-Mo Ahn ${ }^{3,4}$ \\ and Chung-Ho Ryu'* \\ ${ }^{1}$ Division of Applied Life Science (BK21 program), Institute of Agriculture and Life Science, Gyeongsang National University, Jinju 660-701, \\ Korea \\ ${ }^{2}$ Yang-Ji Food Co., Ltd Sacheon 664-839, Korea \\ ${ }^{3}$ Environmental Health Center for Atopic Diseases, Samsung Medical Center Department of Pediatrics, Seoul 135-230, Korea \\ ${ }^{4}$ Samsung Medical Center, Sungkyunkwan University School of Medicine, Seoul 135-230, Korea
}

Received January 27, 2012 /Revised March 19, 2012 /Accepted March 20, 2012

\begin{abstract}
Soybean is one of the most common food materials causing food hypersensitivity reactions in Korea. In this study, we have investigated the effect of roasting and fermentation on the allergenicity of soybean. Three kinds of soybean (Daepung, Daewon, and Taegwang) were prepared as raw, roasted, and fermented by Bacillus subtilis GSK 3580, and then their proteins were extracted. The proteins were separated using SDS-PAGE, and the detection of IgE specific to soybean proteins was performed by immunoblotting using 7 sera of soybean allergy patients and non-allergic control individuals. Serum specific IgE to soybean was measured by ELISA. The SDS-PAGE of raw soybean proteins showed various-sized bands ranging from 9 to $76 \mathrm{kDa}$, which are known as major allergens. In particular, 9, 21, $34,52,72$, and $76 \mathrm{kDa}$ proteins are known as LTP, Kunits trypsin inhibitor, Gly m Bd 30K, $\beta$-subunit, $a$-subunit, and $a^{\prime}$-subunit of $\beta$-conglycinin, respectively; these are major allergens in soybean. In contrast, only peptides of less than $35 \mathrm{kDa}$ were found in roasted and fermented soybeans. IgE immunoblot analysis of three roasted species of soybeans commonly detected at 38-40 kDa and 10-15 kDa. The protein bands in fermented soybean showed very weak signals or were not detected. In addition, the reactivity of most patients' sera to soybean was decreased after roasting and fermentation. With these results, it may be concluded that the allergenicity of soybeans is reduced by the roasting and fermentation processes. It is supposed that allergenic proteins in soybean were degraded by heat treatment methods and proteolytic enzymes were secreted from fermenting microorganisms.
\end{abstract}

Key words : Soybean, food allergy, allergenicity

\section{서 론}

알레르기는 항원성 단백질(allergen)과의 반복되는 접촉으 로 발생되는 신체 과민반응(hypersensitivity)으로, 다음과 같 은 세 단계를 거쳐 진행된다. 우선, allergen과의 처음 접촉에 서 allergen을 인식하는 면역물질(antibody)이 체내에서 생성 되고, 이 면역물질이 알레르기에 관여하는 세포에 부착되고, 이후 allergen과의 반복 접촉에서 면역물질과 allergen이 결합 함으로써 알레르기 관여세포에서 화학매개체가 세포 밖으로 분비되어 조직에서 여러 가지 알레르기 증상을 일으킨다[27]. 특히 식품 알레르기는 지난 20년간 전세계적으로 중요한 건강 관련문제 중 하나로 대두되고 있으며 삶의 질에 있어서도 심 각한 부정적 효과를 낳고 있는 실정이며[20], 나라마다 그 빈도 나 유발하는 원인식품들에 차이가 있는데 이는 그 나라의 유 전적 특성, 문화, 식습관 및 조리법 그리고 생후 초기에 노출되

*Corresponding author

Tel : +82-55-772-1905, Fax : +82-55-772-1909

E-mail : ryu@gnu.ac.kr
는 알레르기 유발 식품의 종류와 깊은 연관이 있는 것으로 알려져 있다[8]. 서구의 경우 3세 미만의 소아에서 약 $8 \%$, 성인 의 약 $2 \%$ 에서 유병률을 보이며 연령이 증가하면서 면역 관용 이 유도된다[24]. 우유의 경우 3-5세에 80-85\% 면역 관용이 유 도되는 반면[14], 콩 알레르기는 면역 관용이 잘 생기지 않는 식품 알레르기로 알려져 있다. 우유 알레르기의 경우 선상 항 원 결정기가 지속적인 알레르기에 기여한다는 보고가 있지만, 면역 관용이 잘 유도되지 않는 견과류 및 콩 알레르기에서는 아직 밝혀지고 있지 않다[32]. 콩은 경제적으로 매우 중요한 작물로, 우리나라를 비롯하여 중국, 일본, 유럽 각지와 미국 등에서 널리 재배되어 섭취되고 있는 음식물이다. 식이 단백 질의 주요 공급원인 콩은 특별히 한국 사람의 식생활에서 큰 비중을 차지하는데 두부, 된장, 간장, 콩가루, 콩기름, 콩나물 로 섭취하는 등 여러 형태의 음식으로 사용되고 있으며 그로 인한 우리나라 국민들의 콩 단백질에 대한 감작 정도도 증가 하고 있다[15,28]. 콩 알레르기의 증상은 땅콩 알레르기처럼 생명에 위협을 주는 반응을 일으키는 경우는 흔하지 않다[26]. 심한 음식물 알레르기 반응으로 인해 중환자실에서 치료가 
필요했던 총 61 예 중 원인 음식물로는 땅콩 20예, 콩 16 예였다 는 보고도 있다[9]. 또한 성인에서 콩 섭취와 관련된 음식물 의존성 운동 유발성 아나필락시스에 관한 보고 등, 콩 알레르 기는 다양한 임상양상을 나타낸다[10,30]. 식품 알레르기를 일 으키는 항원성 물질의 함량은 식품 소재 수확, 건조, 저장, 조 리법에 의해 달라질 수 있다. 가열 처리에 따른 식품의 알레르 기성 변화에 대한 연구가 활발하게 진행되고 있는데 참치나 연어의 경우에는 가열처리 후에 알레르기성을 상실하고[1], 계 란의 경우에는 열처리 후에도 알레르기성이 계속 존재하는 것으로 알려져 있다[32]. 열처리 과정은 식품 단백질의 알레르 기 항원성을 변형시킴으로써, 저 알레르기 식품 제조의 한 방 법으로 이용되고 있는데 실제 같은 식품이라도 조리법에 따라 환자의 임상증상이 달라지는 것을 볼 때, 열처리 방법에 따른 알레르기 항원성의 변화에 관한 연구는 식품에 있어서도 유효 한 정보를 제공하리라 생각된다.

이에 본 연구에서는 다양한 콩 가공식품의 제조 시 사용되 는 열처리 방법에 따라 세 가지 품종의 콩 단백질을 추출하여 구성단백의 변화를 살펴보고, 콩 특이 $\mathrm{IgE}$ 항체 수치가 높은 환아 혈청들을 사용하여 immunoblotting과 enzyme linked immunosorbent assay (ELISA)의 방법을 통해 열처리 방법에 따른 품종별 콩 알레르기성 변화를 비교, 분석하였다.

\section{재료 및 방법}

\section{대상환자 및 혈청확보}

2010 년 3월부터 2010 년 8 월까지 삼성서울병원 소아과에 내원하여 Hanifin의 진단기준[11]에 따라 혈청 내 콩에 대한 특이 $\operatorname{IgE}$ 수치가 $30 \mathrm{kU} / 1$ 이상을 보인 환아 7명을 대상으로 하였다(Table 1). 이 중 실제로 대두에 대한 알레르기 증상을 보인 경우는 4 명이었고, 나머지는 이전에 대두를 먹은 경험이 없는 환아였다. 혈청 내 콩 특이 IgE는 CAP-FEIA (Pharmacia, Uppsala, Sweden)으로 측정하였고, 정상 대조군은 콩 특이 $\mathrm{IgE}$ 가 없으면서 콩 섭취 후 어떠한 증상도 발현되지 않는 건강 한 성인으로 하였으며, 혈청은 $-80^{\circ} \mathrm{C}$ 에 보관하여 사용하였다.

\section{실험재료}

본 실험에 사용된 콩은 국립 식량과학원으로부터 제공 받았
으며, 장류 제조용으로 적합한 품종으로 국내에서 가장 많이 유통되고 있는 대풍, 대원, 태광 품종을 시료로 사용하였다. 발효 공정에서 사용한 균주는 경상대학교 생물공학실험실에 서 분리한 Bacillus subtilis GSK 3580을 사용하였다.

\section{열처리 방법}

세 가지 품종의 콩의 열처리 방법에 따른 항원성의 변화를 확인하기 위해 볶는 공정은 $130-140^{\circ} \mathrm{C}$ 로 가열된 frying pan에 서 7 분 실행하였으며, 발효 공정은 콩을 콩 무게의 2.2 배가 될 때까지 수침하여 1 시간 물빼기 한 후 $121^{\circ} \mathrm{C}, 25$ 분 가압 증자하 여 충분히 냉각 시키고 Bacillus subtilis GSK 3580 을 $10^{6}$ $\mathrm{CFU} / \mathrm{g}$ 농도로 접종하여 $37^{\circ} \mathrm{C}, 24$ 시간 발효시켰다.

\section{콩 단백질 추출 및 정량}

열처리하지 않은 콩과 열처리한 콩을 곱게 분쇄하고 시료 내 존재하는 지방성분을 제거하기 위하여 5 배의 $n-H e x a n$ 을 넣고 실온에서 1 시간 동안 교반시키는 과정을 두 번 반복하였 다. 이렇게 하여 얻은 분말은 $30 \mathrm{mM}$ Tris- $\mathrm{HCl}(\mathrm{pH} 8.0), 1 \mathrm{M}$ $\mathrm{NaCl}$ 과 함께 1:10 (w/v) 비율로 섞은 후 실온에서 micro tube mixer MT-360 (Tomy Seiko Co., Ltd., Japan)를 이용하여 3시 간 동안 단백성분을 추출하여 용출시켰다. 이 용액을 $4^{\circ} \mathrm{C}$, $12,000 \mathrm{rpm}$ 에서 10 분간 원심 분리한 후, 상징액을 사용 전까지 $-20^{\circ} \mathrm{C}$ 에서 보관하였다. 추출된 단백질은 Bradford method [5] 에 근거한 Bio-Rad의 Protein Assay [3]로 정량하였고, 표준물 질로 BSA (bovine serum albumin)을 사용하였다.

Sodium dodesylsulfate-polyacrylamide gel electrophoresis (SDS-PAGE)

열처리 방법에 따른 품종별 콩 알레르겐 함량의 변화를 추 정하기 위하여 Laemmli의 방법[7,17]에 준하여 SDS-PAGE를 실시하였다. Gel은 $12 \%$ separating gel과 5\% stacking gel을 이용하였고, 시료는 3 배 농도의 sample buffer (1 M Tris-HCl: $\mathrm{pH}$ 6.8, 50\% glycerol, 10\% SDS, 2-mercaptoethanol, 1\% bromphenol blue)와 2:1 (w/v)로 섞은 후 끓는 물에서 5 분간 가열한 뒤 lane 당 $3 \mu \mathrm{g} / \mathrm{ml}$ 로 분리하였다. 전기 영동은 100 volt에서 90분 시행하였으며 전기영동 후, gel은 Coomassie staining solution (1.0 g Coomassie Blue R-250, 450 ml meth-

Table 1. Clinical characteristics of 7 patients with soybean allergy and atopic dermatitis

\begin{tabular}{ccccc}
\hline No. & Sex & Age $(\mathrm{yr})$ & Total $\operatorname{IgE}(\mathrm{kU} / \mathrm{l})$ & Soybean specific IgE $(\mathrm{kU} / \mathrm{l})$ \\
\hline 1 & $\mathrm{~F}$ & 2 & 1376 & 49.2 \\
2 & $\mathrm{M}$ & 2 & 5001 & 60.9 \\
3 & $\mathrm{~F}$ & 1 & 865 & 28.7 \\
4 & $\mathrm{M}$ & 2 & 5001 & 54.1 \\
5 & $\mathrm{~F}$ & 2 & 406 & 36.3 \\
6 & $\mathrm{~F}$ & 1 & 765 & 39.7 \\
7 & $\mathrm{M}$ & 1 & 559 & 55.2 \\
\hline
\end{tabular}


anol, 450ml $\mathrm{H}_{2} \mathrm{O}, 100 \mathrm{ml}$ glacial acetic acid, $800 \mathrm{ml} \mathrm{H} \mathrm{H}_{2} \mathrm{O}$ )로 20분간 염색하고 Coomassie destaining solution $(100 \mathrm{ml}$ methanol, $100 \mathrm{ml}$ glacial acetic acid, $800 \mathrm{ml} \mathrm{H} \mathrm{H}_{2}$ )로 적절히 탈색 후 구성단백들의 분포를 비교분석 하였다.

\section{lgE Immunoblot 분석}

Immunoblotting은 Son, Scheurer 등의 방법에 준하여 실시 하였다[25,29]. SDS-PAGE 후 분리된 단백질은 PVDF (polyvinylidene difluoride) membrane (Bio-Rad, USA)에 trasnsfer buffer (tris base $11.5 \mathrm{~g}$, Glycine $58 \mathrm{~g}$, 10\% SDS 20 $\mathrm{ml}$, Methanol $400 \mathrm{ml}, 1500 \mathrm{ml} \mathrm{H} \mathrm{H}_{2}$ )를 사용하여 100 volt에서 60 분 electrotransfer 하고 비특이적 결합을 방지하기 위해 $5 \%$ Skim milk가 포함된 TBST (tris bufferd saline, pH 7.5 containing $0.05 \%(\mathrm{v} / \mathrm{v})$ tween 20) 용액으로 $4{ }^{\circ} \mathrm{C}$ 에서 하룻밤 blocking 하였다. TBST 용액으로 3회 세척 후, 환아 혈청은 $2.5 \%$ Skim milk가 포함된 TBST로 1:100으로 희석하여 실온에 서 2시간 반응시키고 TBST 용액으로 3회 세척 후, 1:1000으로 희석시킨 peroxidase-conjugated anti-human $\mathrm{IgE}$ 와 실온에서 1 시간 반응시켰다. TBST 용액으로 3회 세척 후, ECL (enhanced chemiluminescense, Amersham Pharmacia Biotech, Buck-inghamshire, UK)를 이용하여 X-ray 필름(Eastman Kodak, Rochester, N.Y., USA)에 감광시켜 발색반응을 관찰하였다.

\section{Enzyme-linked immunosorbent assay (ELISA)}

ELISA는 Engvall와 Perlmann등의 방법에 준하여 실시하 였다[9]. 품종별로 열처리하지 않은 생콩, 볶은 콩, 증숙하여 발효시킨 콩의 추출물을 항원으로 사용하였고, 각각의 추출물 을 96-well plate (NUNC, Denmark)에 최종 농도가 $10 \mu \mathrm{g} / \mathrm{ml}$ 이 되도록 PBS (20 mM sodium phosphate, $150 \mathrm{mM} \mathrm{NaCl}$, $2.7 \mathrm{mM} \mathrm{KCl}, \mathrm{pH}$ 7.4)로 희석하여 각 $100 \mu \mathrm{l}$ 씩 분주하고 $4^{\circ} \mathrm{C}$ 에 서 하룻밤 coating하였다. 다음날 PBST (phosphate buffered saline containing $0.05 \%$ (v/v) tween 20)로 3회 세척하였으며, 비특이적 결합을 방지하기 위해 blocking buffer $(10 \%$ fetal bovine serum-phosphate buffered saline)를 이용하여 1시간 blocking 한 후 다시 PBST로 3회 세척하였다. 여기에 PBS를 이용해 1:100으로 희석한 혈청을 $100 \mu \mathrm{l}$ 씩 가하고 $37^{\circ} \mathrm{C}$ 에 2시 간 반응시켰다. PBST로 3 회 세척한 후, 1,000 배로 희석시킨 peroxidase-conjugated anti-human $\mathrm{IgE}$ 도 $37^{\circ} \mathrm{C}$ 에 2 시간 반응 시켰다. PBST로 4 회 세척한 후, TMB substrate solution (3,3,5,5'-tetramethylbenzidine, citrate-phosphate buffer 10 $\left.\mathrm{ml}, 30 \% \mathrm{H}_{2} \mathrm{O}_{2} 2 \mu \mathrm{l}\right)$ 를 첨가하여 각 well에 $100 \mu \mathrm{l}$ 씩 넣고 10분 간 발색시켰다. $1 \mathrm{M}$ phosphoric acid를 첨가하여 발색을 정지 시킨 후 $450 \mathrm{~nm}$ 에서 흡광도를 측정하였다.

\section{통계학적 분석}

모든 실험결과는 3 회 이상 실험을 반복하여 얻은 자료를
이용하여 평균 \pm 표준편차로 나타내었고, 유의성 검증을 위하 여 SPSS 12.0 for window를 이용하여 일원배치분산분석 (one-way ANOVA)을 실시하였으며 control과의 유의한 차이 를 검증하기 위하여 Tukey's 사후검정을 실시하였다( $p<0.05)$.

\section{결과 및 고찰}

\section{단백질 농도 변화}

열처리하지 않은 콩과 볶은 콩, 발효한 콩의 품종별 단백질 농도를 측정한 결과, Fig. 1에 나타난 바와 같이 열처리에 따 른 단백질 농도 차이를 확인할 수 있었다. 대풍 품종의 경우 각각 $3.07,1.68,1.20 \mathrm{mg} / \mathrm{ml}$, 대원 품종의 경우 $2.99,1.65,1.20$ $\mathrm{mg} / \mathrm{ml}$, 태광 품종의 경우 $3.03,1.66,1.10 \mathrm{mg} / \mathrm{ml}$ 로 열처리 한 콩은 열처리하지 않은 콩에 비해 2-3배 가량 단백질 농도 가 낮게 측정되었다. 이것은 단백질이 열처리에 의해 amino acid, peptide 등으로 분해됨으로써 나타나는 결과라 사료된 다. Son 등[27]의 열처리에 따른 콩 단백 질 Allergenicity 변화 에 관한 연구에서 열처리에 따라 단백질의 미세한 농도 차이 를 확인할 수 있었다고 보고하여 본 연구와 유사한 결과를 나타내었다.

\section{콩 항원에 대한 SDS-PAGE}

열처리하지 않은 콩과 열처리한 콩의 품종별 단백구성을 알아보기 위하여 추출한 단백질을 사용하여 SDS-PAGE실시 한 결과, 다양한 콩 가공식품의 제조를 위해 사용되는 열처리 방법에 따라 단백질 변화가 확연하게 관찰되었다. 열처리 하 지 않은 콩은 Fig. 2A와 같이 9, 12-15, 17, 19-21, 25, 30-35, $47,52,70-76 \mathrm{kDa}$ 에 걸쳐 다양한 분자량의 단백질 밴드들이 gel에서 골고루 분포하였다. 또한 이들 중에서 LTP $(9 \mathrm{kDa})$, kunits trypsin inhibitor (21 kDa), Gly m Bd 30K (34 kDa),

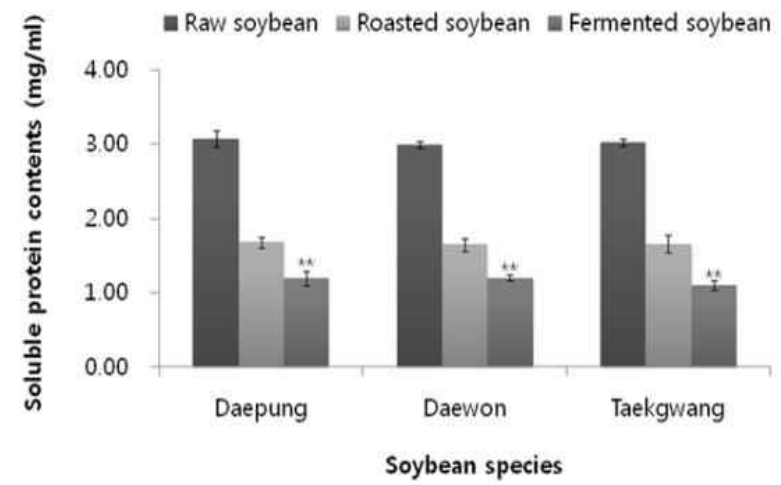

Fig. 1. Change of soluble protein contents by thermal treatment methods (Raw, roasting and fermentation). Data represent the mean $\pm \mathrm{SD}$ from three separate experiments. ${ }^{*} p<0.05,{ }^{* *} p<0.01$, significant compared control. 
ß-conglycinin ( $\beta$-subunit: $52 \mathrm{kDa}$, a-subunit: $72 \mathrm{kDa}, \mathrm{a}^{\prime}$-subunit: $76 \mathrm{kDa})$ 등[16,22] 콩의 주요 알레르겐으로 알려져 있는 단백질로 추정되는 밴드들이 뚜렷하게 관찰되었다. Fig. $2 \mathrm{~B}$ 의 열처리하지 않은 콩의 구성단백들과 비교해 보았을 때, 열처 리한 콩에서는 전체적으로 단백질 밴드가 약해지는 것을 확인 할 수 있었는데 볶은 콩의 경우 9, 15-17, 21, 25, $35 \mathrm{kDa}$ 에서 단백질 밴드가 희미하게 나타났고 그 이상에서는 관찰되지 않아 $35 \mathrm{kDa}$ 이하로 분해된 것을 확인할 수 있었다. 발효콩의 경우도 $13,21,25 \mathrm{kDa}$ 에서 단백질 밴드가 희미하게 나타났지 만 그 이상에서는 관찰되지 않아 $25 \mathrm{kDa}$ 이하로 분해된 것으 로 보인다. 그러나 공통적으로 $21,25 \mathrm{kD}$ 에 해당하는 단백질 밴드는 열처리 방법에 관계없이 희미하게나마 일정한 단백질 밴드 분포를 보였는데 이것은 $21,25 \mathrm{kDa}$ 에 해당하는 단백질 이 열에 안정적이며 저항성이 있기 때문인 것으로 생각된다. 품종별로 비교했을 때 볶은 대풍 품종에서 대원, 태광 품종보 다 약한 단백질 밴드를 보였고 발효한 3 가지 품종의 콩에서는 큰 차이를 보이지 않았다. 콩의 알레르기성을 낮추기 위해서 주 항원인 Gly m Bd $30 \mathrm{~K}$ 의 구조를 변경시키는 여러 다양한 방법들이 시도되고 있으며 그 방법으로 열처리, 효소처리, 발 효처리, 탄수화물 결합, 품종 개량, 유전자 재조합 등이 연구되 고 있는데, 이 중에서 국내 및 일본에서는 콩을 발효시킨 형태 의 식품들이 널리 이용되기 때문에 발효를 통해 대두의 알레 르기성을 감소시키는 시도가 보다 활발하게 진행되고 있다. 발효 과정은 미생물로부터 분비되는 효소에 의한 가수분해 과정으로 큰 분자량을 가진 단백성분을 펩타이드나 아미노산 형태로 줄여 항원성을 최소화 하는 방식인데[31], 일본에서 시 행된 연구 중에서 natto발효와 유사한 방식으로 B. subtilis 로 부터 분비된 protease를 추출한 물질로 멸균 증자 대두를 발효 시킨 결과 대두단백이 분자량 $10 \mathrm{kDa}$ 이하로 분해됐다[34]고
보고되어 본 연구와 유사한 결과를 보였다.

\section{콩 항원과 환아 혈청과의 $\mathrm{lgE} I \mathrm{~mm} u n o b l o t$ 분석}

품종별로 열처리하지 않은 콩과 열처리한 콩을 환아 혈청 과 immunoblotting한 결과 Fig. 3 에 나타난 바와 같이 혈청 $\operatorname{IgE}$ 와 반응하는 단백질 밴드의 분포는 환아마다 $10 \mathrm{kDa}$ 에서 $80 \mathrm{kDa}$ 에 걸쳐 다양하게 나타났다. 특히 열처리 하지 않은 콩과의 반응에서 콩의 주요 항원으로 알려진 $9 \mathrm{kDa}$ 에서 양성 을 나타낸 환아가 4 명, $21 \mathrm{kDa}$ 에서 5 명, $34 \mathrm{kDa}$ 에서 7명 모두, $52 \mathrm{kDa}$ 에서 1명, $72-76 \mathrm{kDa}$ 에서 양성을 나타낸 환아는 3 명이 었다. 지금까지 알려진 콩의 원인 알레르겐은 21 개 이상이며, $9 \mathrm{kDa}$ 의 LTP는 과일, 채소와 같은 식물에서 유래하는 음식물 에 널리 분포하며, 열과 단백분해효소에 저항성이 강한 것으 로 알려져 있다[6]. 가장 면역학적으로 지배적인 주 항원은 Gly m Bd 30K 또는 P34 로 알려져 있는데 이 알레르겐은 분자 량이 $34 \mathrm{kDa}$ 정도이며, 대두 알레르기 환자의 $65 \%$ 정도에서 immunoblot 분석에서 양성을 나타낸다[13,33]. 성인 알레르 기 환자를 대상으로 했던 국내 연구에서도 콩에 감작을 보인 환자의 $50 \%$ 에서 $34 \mathrm{kDa}$ 위치에서 $\mathrm{IgE}$ 양성 반응이 나타났으 며[21] 본 연구에서도 전체 7명의 환아 모두에서 열처리하지 않은 국내산 장류용 품종의 콩으로 immunoblot 분석한 결과, $34 \mathrm{kDa}$ 부위에서 양성을 보여서 본 연구와 일치되는 소견을 관찰할 수 있었다. 그러나 열처리하지 않은 콩에서 보였던 반 응성이 열처리한 콩에서는 대부분의 환아에서 나타나지 않았 는데, 특히 2, 6, 7번 환아 혈청을 제외한 나머지 환아에서는 gel에서 나타났던 단백질 밴드가 볶은 콩, 발효한 콩과의 환아 혈청 반응에서는 인식되지 않았다. 2, 6, 7번 환아 혈청에 의해 인식된 콩 단백질의 분자량은 환아 혈청마다 차이를 나타내었 는데 2번 환아(Fig. $3 \mathrm{C})$ 의 경우 전체 환아 혈청 중 콩 항원과

\section{( A )}

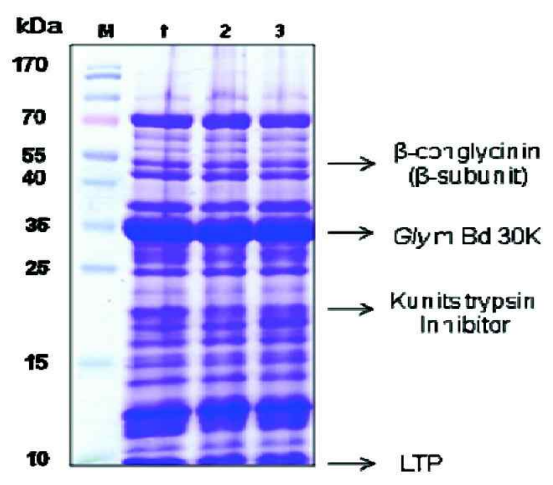

( B )

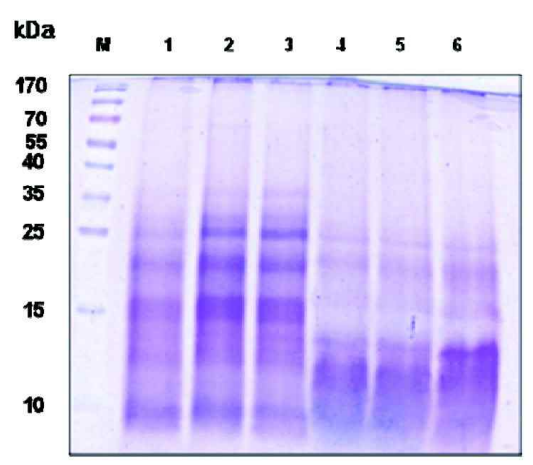

Fig. 2. SDS-PAGE analysis for raw, roasted and fermented soybean proteins. (A), Protein of raw soybeans, M, molecular weight marker; lane 1, raw Daepung species soybean; lane 2, raw Daewon species soybean; lane 3, raw Taegwnag species soybean, (B), Protein of roasted and fermented soybeans, M, molecular weight marker; lane 1, roasted Daepung species soybean; lane 2, roasted Daewon species soybean; lane 3, roasted Taegwnag species soybean; lane 4, fermented Daepung species soybean; lane 5, fermented Daewon species soybean; lane 6, fermented Taegwnag species soybean. 
( A )

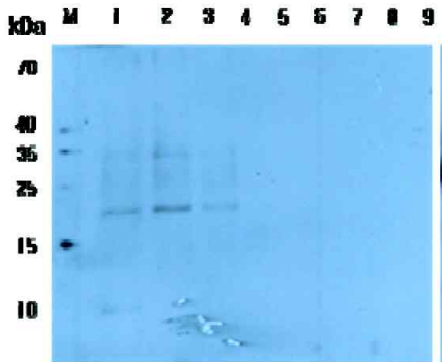

( $E$ )
(B)

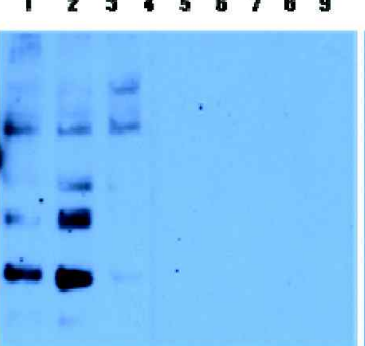

( F )
(C)

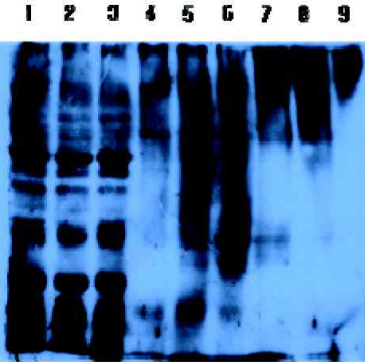

( $G$ )
(D)

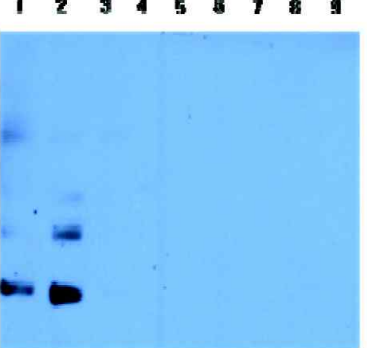

( $\mathrm{H}$ )
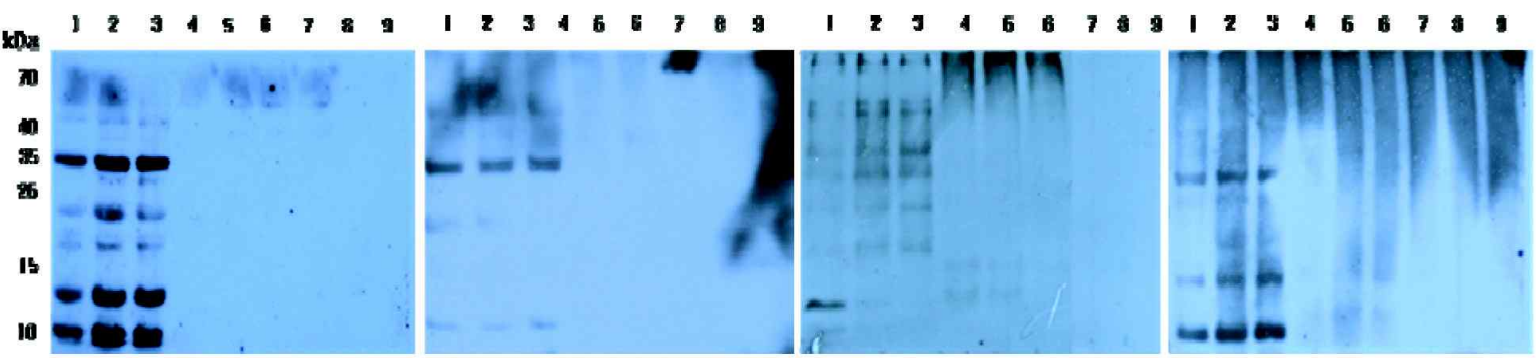

Fig. 3. Immunoblotting analysis of raw, roasted and fermented soybean proteins with allergic patients' sera. (A), non-allergic control individual, (B) (H), sera of soybean allergic patients' No.1 7, respectively; M, molecular weight marker; lane 1, raw Daepung species soybean; lane 2, raw Daewon species soybean; lane 3, raw Taegwnag species soybean; lane 4, roasted Daepung species soybean; lane 5, roasted Daewon species soybean; lane 6, roasted Taegwnag species soybean; lane 7, Fermented Daepung species soybean; lane 8, Fermented Daewon species soybean; lane 9, Fermented Taegwnag species soybean.

가장 강하게 반응하였고 분자량은 대략 $9,21-37 \mathrm{kDa}$ 정도의 단백질이었으며, $50 \mathrm{kDa}$ 이상의 단백질도 확인되었다. 볶음 처리한 대풍 품종은 다른 품종보다 $40 \mathrm{kDa}$ 이하에 해당하는 단백질 밴드의 $\mathrm{IgE}$ 반응성이 약하게 나타났으며 발효한 콩에 서는 대풍 품종만이 $21 \mathrm{kDa}$ 에서 반응성을 보였고 나머지는 $40 \mathrm{kDa}$ 이하에서 단백질 밴드가 나타나지 않았다. 그러나 반 응이 완전히 사라진 것은 아니며 $40 \mathrm{kDa}$ 이상에서 반응성이 남아있음을 확인하였다. 6번 환아(Fig. 3G)의 경우 볶음 처리 한 세가지 품종 모두 10-15 kDa에서 희미하게 반응성을 보였 고 2번 환아와 마찬가지로 $40 \mathrm{kDa}$ 이상에서도 반응성이 남아 있었으나 발효한 콩에서는 반응성을 나타내지 않았다. 7번 환 아(Fig. $3 \mathrm{H})$ 의 경우는 2 번 환아와 비슷한 패턴을 나타냈지만 그 반응성은 낮은 것으로 판단된다. 품종별로 비교했을 때 1 번 과 3 번 환아 혈청이 태광 품종과 반응성이 거의 없으므로 태 광 품종이 항원성이 적은 것으로 보이나 환아 혈청마다 품종 별 반응성에서 큰 차이를 보이므로, 항원성에 관해 결론 내리 기에는 어려움이 있는 것으로 사료된다. 주요한 식품 알레르 겐은 대부분 분자량이 $10 ~ 60 \mathrm{kDa}$ 의 범위에 있는 수용성 glycoprotein이며 알레르기 반응을 일으키기 위해서는 면역학적 활성을 가진 형태로 위장관에 도달하여야 한다. 이러한 단백 질들은 비교적 열처리나 산처리, 단백질 분해효소에 안정한
특성을 갖고 있다[23]. Maleki 등[19]은 땅콩, 새우, 우유, 어류 와 같은 알레르기 유발 빈도가 높은 식품은 열 저항력이 높다 고 보고하여, 본 연구에서의 콩도 품종에 따른 차이가 있는 것으로 생각된다.

\section{콩 품종별, 열처리 방법에 따른 항원성 변화}

혈청 내 콩에 대한 특이 $\mathrm{IgE}$ 수치가 $30 \mathrm{kU} / 1$ 이상을 보인 7 명의 콩 민감성 환아 혈청을 이용하여 ELISA법으로 대풍, 대원, 태광콩의 열처리 방법에 따른 항원성의 변화를 조사한 결과, Fig. 4에서 나타난 바와 같이 대조군과 비교하여 콩 항원 에 대하여 비교적 높은 특이적 반응을 보였다. 특히 콩 특이 $\mathrm{IgE}$ 수치가 높았던 2번과 7번 환아 혈청에서 다른 환아 혈청보 다 높은 수치를 나타내었고, 나머지 환아 혈청은 대등한 유의 적 차이를 나타냈다. 또한 7 명의 환아 중에서 3 번과 5 번의 환아 혈청은 immunoblotting 결과(Fig. 3)에서는 콩의 열처리 에 의해 반응성이 감소되어 검출되지 않았던 반면, ELISA 결 과(Fig. $4 \mathrm{~A}, \mathrm{~B}) 3$ 번 환아에서 높은 반응성을 나타낸 것을 확인 할 수 있었다. 콩 단백질은 이미 사람과 동물에서 알레르기 반응을 일으킨다고 보고되었는데, Bock 등[4]은 콩에 알레르 기를 가진 사람은 콩 추출물에 대한 $\mathrm{IgE}$ 와 $\mathrm{IgG}$ 의 level이 증가 한다고 보고한 바 있다. 콩의 어떤 fraction이 더 항체를 많이 
(A)

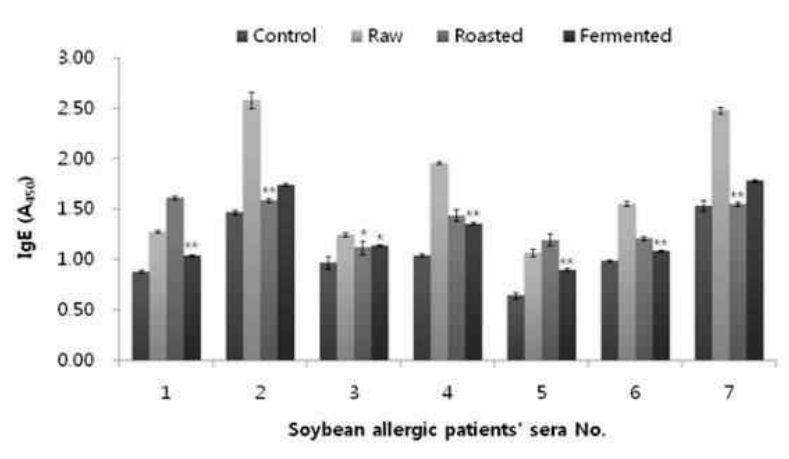

(B)

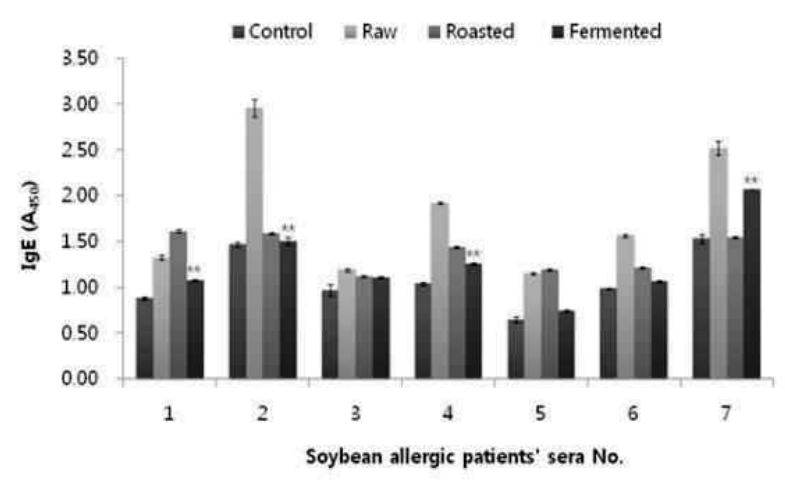

(C)

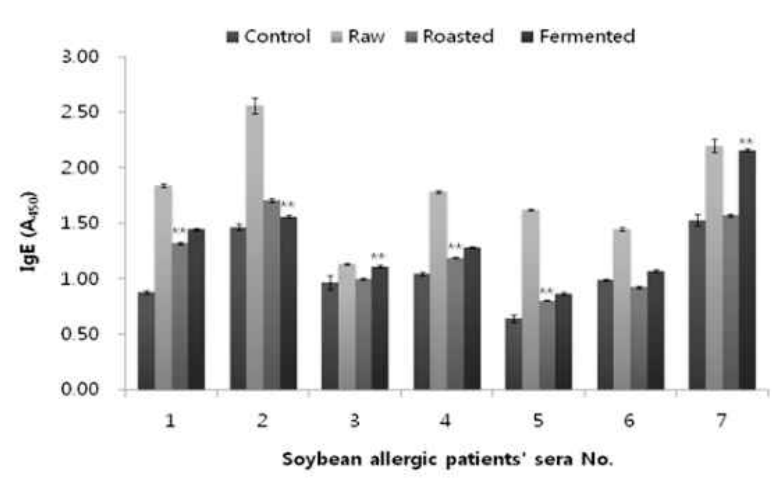

Fig. 4. ELISA analysis of raw, roasted and fermented soybean proteins with soybean allergic patients' sera. (A), Daepung species soybean, (B), Daewon species soybean, (C), Taegwang species soybean; 1 7, The sample number of soybean allergic patients' sera, respectively. Data represent the mean $\pm \mathrm{SD}$ from three separate experiments. ${ }^{*} p<0.05,{ }^{* *} p<0.01$, significant compared control.

생산하는지는 아직 밝혀진 바가 없는데 Burks 등[27]은 콩에 대해 아토피성 피부염과 DBPCFC (Double-blind, placebo-controlled food challenge)에 양성인 아이들을 대상으로 연구한 결과, 어느 특정한 fraction이 주요 allergen이라고 결 론 내릴 수 없었으며 대두 단백질의 많은 fraction에 대해 $\mathrm{IgE}$ 와 IgG가 반응하는 것 같다고 발효한 바 있어 본 연구와 유사
한 결과를 나타냈다. 또한 Hansen 등[12]의 보고에 의하면 구 운 hazelnut은 $\mathrm{IgE}$ affinity가 생 것에 비해 100배 감소함으로 써 열처리에 의한 단백변성으로 항원성의 차이를 보여주었다. 그러나, 구운 땅콩은 생 땅콩에 비해 땅콩 알레르기 환자 혈청 에서 90 배 이상 $\mathrm{IgE}$ 와 결합하여 항원성이 증가함이 보고되어 있으며[19], 또 구운 pecan nut에서도 항원성이 증가했던 보고 가 있어[2] 본 연구와는 대조되는 결과를 보였다. 열처리법은 단백구조를 분명히 변형시키지만, 알레르기 항원성과의 관련 은 명확하지 않다. 알레르기 항원성은 알레르겐, epitope, 숙주 의 면역반응에 대한 다양성, 식품 기질, 열처리시의 온도와 시간, 외부환경의 산도에 따라 달라지기 때문이다. 또한 개인 에 따라 알레르기 반응 정도와 특이 항체가 알레르겐을 인식 하는 epitope가 다르기 때문에 모든 환자들이 동일하게 반응 을 일으키지 않는다[18]는 점을 항상 고려해야 한다. 본 연구의 제한점으로, 대상 환아 7 명은 혈청 특이 $\mathrm{IgE}$ 수치가 $30 \mathrm{kU} / 1$ 이상으로 이 수치는 Sampson 등[24]이 제시한 CAP system을 이용한 "diagnostic decision point"로 73\%의 양성예측치를 가 질 수 있기 때문에 임상적으로 콩 알레르기로 진단되었다. 그 러나 환아의 수가 적으며, 1 2살 사이의 연령대로 국한되어 있고, 이중맹검경구유발시험을 통해 콩 알레르기로 확진된 환 아가 아니라 혈청 콩 특이 $\mathrm{IgE}$ 반응성을 가진 경우이기 때문에 실제로 항원성의 차이를 분석하는데 어려움이 있다고 보여진 다. 추후 열처리 방법에 대한 영향의 평가에 있어서 콩 알레르 기 환자를 대상으로 피부시험 등을 시행한 연구가 이루어진다 면, 본 연구의 실험적인 결론을 뒷받침할 수 있는 임상연구가 될 것이라 사료된다.

\section{감사의 글}

본 연구는 농림수산식품부의 지원 연구과제(과제번호: 111026-3) 연구비 지원과 BK 21 program 지원으로 수행 되었 기에 이에 감사드립니다. 또한 연구에 사용된 콩 시료를 제공 해 주신 밀양 국립식량과학원에 감사드립니다.

\section{References}

1. Bernhisel-Broadbent, J., Scanolon, S., Strause, D. and Sampson, H. A. 1992. Clinical relevalence of altered fish allergenicity secondary to various preparation methods. $J$. Allergy Clin. Immunol. 90, 622-629.

2. Berrens, L. 1996. Neoallergens in heated pecan nut: products of maillard-type degradation? Allergy 51, 277-278.

3. Bio-Rad Laboratories. 1998. Bio-Rad protein assay. Bio-Rad Lab., Hercules. CA, USA.

4. Bock, S. A., Lee, Y., Remigo, L. K. and May, C. D. 1978. Studies of hypersensitivity reactions to foods in infants and children. J. Allergy Clin. Immunol. 62, 327-332.

5. Bradford, M. M. 1976. A rapid and sensitive method for 
the quantification of microgram quantities of protein utilizing the principle of protein-dye binding. Anal. Biochem 72, 248-254

6. Choi, S. J., Kim, H. M., Hur, G. Y., Shin, S. Y. and Park, H. S. 2008. A case of rice induced food allergy in an adult patient presenting multiple food allergies. J. Asthma Allergy Clin. Immunol. 28, 64-69.

7. Chun, W. S., Lee, K. S., Hong, C. H. and Lee, S. Y. 2000. A study on the cross-allergenicity between buckwheat and rice flour using IgE-immunoblot inhibition and ELISA-inhibition test. Pediatr. Allergy Respir. Dis (Korea). 10, 161-170.

8. Dalal, I., Binson, I., Reifen, R., Amitai, Z., Shohat, T. and Rahmani, S. 2002. Food allergy is a matter of geography after all: sesame as a major cause of severe IgE-mediated food allergic reactions among infants and young children in Israel. Allergy 57, 362-365.

9. Engvall, E. and Perlmann, P. 1971. Enzyme-linked immunosorbent assay, ELISA. Immunochemistry 8, 871-877.

10. Foucard, T. and Malmheden, Y. I. 1999. A study on severe food reactions in Sweden-is soy protein an underestimated cause of food anaphylaxis? Allergy 54, 261-265.

11. Hanifin, J. M. and Rajka, G. 1980. Diagnostic features of atopic dermatitis. Acta. Derm Venerel. 92, 44-47

12. Hansen, K. S., Ballmer-Weber, B. K. and Luttkope, D. 2003. Roasted hazelnuts-allergenic activity evaluated by double-blind, placebo-controlled food challenge. Allergy 58, 132-138.

13. Helm, R. M., Cockrell, G., Connaughton, C., West, C. M., Herman, E. and Sampson, H. A. 2000. Mutational analysis of the IgE-binding epitopes of P34/Gly m Bd 30K. J. Allergy Clin. Immund. 105, 378-384.

14. Host, A. 1989. Frequency of cow's milk allergy in childhood. Ann. Allergy Asthma Immunol. 1, 33-37.

15. Kim, S. H., Kim, H. M., Ye, Y. M., Nahm, D. H., Suh, C. H. and Park, H. S. 2004. IgE Sensitization and identification of IgE binding components of soybean allergen in adult allergy patients. J. Asthma Allergy Clin. Immunol. 24, 331-336.

16. Krishnan, H. B., Kim, W. S., Jang, S. C. and Kerley, M. S. 2009. All three subunits of soybean $\beta$-Conglycinin are potential food allergens. J. Agric. Food Chem 57, 938-943.

17. Laemmli, U. K. 1970. Cleavage of structural proteins during the assembly of the head of bacteriophage T4. Nature 227, 680-685.

18. Lee, J. H., Lee, Y. W., Shin, Y. S., Park, H. S., Hong, C. S. and Park, J. W. 2010. Measurement specific IgE against recombinant 16-kD and 19-kD buckwheat allergens for the diagnosis of buckwheat allergy. J. Asthma Allergy Clin. Immund. 30, 209-215.

19. Maleki, S. J., Chung, S. Y. and Champagne, E. T. 2000. The effects of roasting on the allergic properties of peanut proteins. J. Allergy Clin. Immunol. 106, 763-768.

20. Marklund, B., Ahlstedt, S. and Nordstrom, G. 2006. Health-related quality of life in food hypersensitive school children and their families: parents' perceptions. Health Qual Life Outcomes 4, 48.

21. Ogawa, T., Tsuji, H., Bando, N., Kitamura, K., Zhu, Y. L. and Hirano, H. 1993. Identification of the soybean allergenic protein, Gly $\mathrm{m} \mathrm{Bd} 30 \mathrm{~K}$, with the soybean seed $34-\mathrm{kDa}$ oil-body-associated protein. Biosci. Biotechnol. Biochem 57, 1030-1033.

22. Oh, M. H. and Noh, Y. H. 1999. Expression and purification of soybean $\beta$-Conglycinin from Escherichia coli. J. Food Nutr. 12, 184-190.

23. Park, J. Y., Ahn, J. Y., Hong, H. O. and Hahn, Y. S. 2004. Reduction of allergenicity of wheat flour by enzyme hydrolysis. J. Food Sci. Technol. 36, 152-157.

24. Sampson, H. A. 1999. Food allergy. Part 1: Immunopathogenesis and clinical disorders. J. Allergy Clin. Immunol. 103, 717-728.

25. Scheurer, S., Son, D. Y., Boehm, M., Karamloo, F., Franke, S., Hoffmann, A., Haustein, D. and Vieths, S. 1999. Cross-reactivity and epitope analysis of Pru a 1, the major apple cherry allergen. Mol. Immunol. 36, 155-167.

26. Sicherer, S. H., Sampson, H. A. and Burks, A. W. 2000. Peanut and soy allergy: a clinical and therapeutic dilemma. Allergy 55, 515-521.

27. Son, D. Y., Lee, B. R., Shon, D. W., Lee, K. S., Ahn, K. M., Nam, S. Y. and Lee, S. I. 2000. Allergenicity change of soybean proteins by thermal treatment. J. Food Sci. Technol. 32, 959-963.

28. Son, D. Y., Lee, C., Park, K. H., Oh, S. S., Lee, S. I., Ahn, K. M., Han, Y. S., Nam, S. Y. and Yoon, K. R. 2001. Prevalence of soy allergy by cow milk-allergic infants in Korea. J. Food Sci. Technol. 33, 501-505.

29. Son, D. Y., Scheurer, S., Haustein, D. and Vieths, S. 1999. Follen-related food allergy: cloning and immunological analysis of isoforms and mutants of Mal d 1, the major apple allergen, and Bet v 1, the major birch pollen allergen. Eur. J. Nutr. 38, 201-215.

30. Taramarcaz, P., Hauser, C. and Eigenmann, P. A. 2001. Soy anaphylaxis. Allergy 56, 792.

31. Tsai, E., Yeung, J., Gold, M., Sussman, G., Perelman, B. and Vadas, P. 2003. Study of the allergenicity of plant protein hydrolysates. Food Allergy Intolerance 4, 117-126.

32. Virture, C. M. and Witting, H. J. 1970. Allergenicity of egg protein fraction as determined by histamine release from human lung tissue. Fed Proc. 29, 576-582.

33. Yamanishi, R., Tsuji, H., Bando, N., Yamada, Y., Nadaoka, Y. and Huang, T. 1996. Reduction of the allergenicity of soybean by treatment with proteases. J. Nutr. Sci. Vitaminol (Tokyo). 42, 581-587.

34. Yamanishi, R., Huang, T., Tsuji, H., Bando, N., Kimoto, M. and Ogawa, T. 1995. Reduction of the soybean allergenicity by the fermentation with Bacillus natto. Food Sci. Technol. $1,14-17$. 


\section{초록 : 열처리 방법에 따른 품종별 콩 단백질의 항원성 변화}

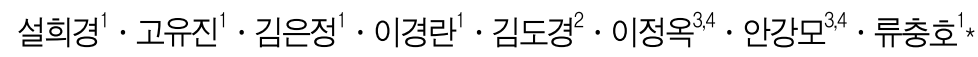

( ${ }^{1}$ 경상대학교 응용생명과학부(BK 21 프로그램) · 농업생명과학연구원, ${ }^{2}$ 양지푸드· ${ }^{3}$ 삼성서울병원 아토피환 경보건센터, ${ }^{4}$ 성균관대학교 의과대학 삼성서울병원 소아청소년과)

콩은 우리나라에서 과민성 알레르기를 일으키는 대표적인 식품 중의 하나로, 식품으로 섭취 시에 가열 및 발효 가공을 통한 형태로 섭취한다. 이에 본 연구에서는 콩에 알레르기 반응을 일으키는 7 명의 환아 혈청과 1 명의 정 상인 혈청을 이용하여 열처리 방법에 따른 품종별 콩(대풍, 대원, 태광)의 알레르기성에 미치는 영향을 조사하였 다. 단백질을 추출하여 SDS-PAGE, immunoblotting 및 ELISA 방법을 통하여 반응성을 조사한 결과, SDS-PAGE 상에서 열처리하지 않은 세가지 품종의 경우 9-76 kDa 위치에서 다양한 단백질 밴드를 보였는데 특히 9, 21, 34, 52,72 그리고 $76 \mathrm{kDa}$ 의 단백질들은 각각 LTP, Kunits trypsin inhibitor, Gly m Bd 30K, $\beta$-conglycinin의 $\beta$ subunit, a-subunit와 a'-subunit로 주요한 콩 알레르겐으로 알려져 있다. 반면에 볶은 콩, 발효한 콩에서는 35 $\mathrm{kDa}$ 이하로 완전히 분해되어 열처리 방법을 통해 단백의 항원성이 줄어드는 것을 확인할 수 있었다. IgE immunoblotting 을 통한 세 가지 품종의 볶은 콩과 콩 알레르기 환아 혈청과의 반응에서는 공통적으로 $38-40$ $\mathrm{kDa}$ 과 10-15 $\mathrm{kDa}$ 에서 단백질 밴드를 보였으나 발효한 콩에서는 대부분 반응성이 약하거나 나타나지 않았다. ELISA 결과, immunoblotting 분석과 동일하게 대부분의 환아 혈청과 반응시에 볶은 콩과 발효한 콩에서 비교적 낮은 수치를 보였다. 결론적으로 콩에 존재하는 알레르겐 단백질은 열처리와 발효 미생물이 분비하는 단백질 분 해효소에 의해 대부분의 환아에서 콩 단백질과의 반응성이 약화되는 것으로 사료된다. 